\title{
Effect of Different Levels of Humic Acid and Mineral Fertilizers on Growth and Productivity of Sunflower
}

\author{
Mourad, KH. A. D and W. MA. K. Teileb \\ Oil Crops Dept., field Crops Res. Inst., Agric. Res. Center., Giza, Egypt
}

Received: $13 / 05 / 2019$

\begin{abstract}
Two field experiments were conducted out at Itay EL-Baroud Agricultural Research Station to investigate the effect of different levels of humic acid and mineral fertilization alone or in combination on two sunflower cultivars, Sakha 53 and G102 during two summer seasons 2016 and 2017. The treatments were, i.e. T1 (100\% mineral fertilizers + zero humic acid), T2 (75\% mineral fertilizers +2 litters of humic acid/feddan), T3 $(50 \%$ mineral fertilizers +2 litter of humic acid/feddan), T4 (50\% mineral fertilizers +1 litter of humic acid/feddan) and T5 ( $0 \%$ mineral fertilizers +2 litter of humic acid/feddan), foliar application of humic was done on 25, 35 and 45 day after sowing (DAS). The experiments were designed in RCBD using split plot with three replications. The results indicated that highly significant difference were found between sunflower cultivars, also found between fertilization treatments during the two seasons, Sakha 53 recorded the best values for plant height, head diameter, seed yield/plant and seed yield/fad, while Giza 102 achieved desirable values for days to flowering and oil \%. The treatments T1 and T2 exhibited the best results for most studied characters such as plant height, head diameter $(\mathrm{cm})$, stem diameter $(\mathrm{cm})$, no. of seeds/plant, 1000-seeds weight/plant and seed yield/fad with exception of oil \% and physiological maturity date. Best value of benefit cost ratio was obtained by T1 and T2 among treatments and Sakha 53 compared to Giza 102.
\end{abstract}

Keywords: Sunflower, humic acid, fertilization, productivity, growth

\section{INTRODUCTION}

Sunflower is one of the most important oil crops occupying the fourth place in the world. Worldwide production of sunflower has increased and peaked during the 1998-1999 period Duane R. Berglund (2007). The sunflower stands out for its high level of oil production, about $40 \%$ Thomaz et al. (2012), which is considered to be of high quality Izquierdo et al. (2002), as well as presenting interesting agronomic characteristics and being easy to adapt to systems used with other annual crops Ghobadian et al. (2008). Sunflower seeds contain a high concentration with a high proportion of polyunsaturated fatty acids, where oil contains a high percentage of linoleic acid (52-62\% from the total fatty acid content) which reduces cholesterol content in human blood, also contains about $20 \%$ of protein so it considered as a good fodder for cattle and poultry. Nowadays sunflower oil can use as a fuel energy. Furthermore green leaves of sun flower can be utilized as a forage crop due to their high content of protein. In Egypt, due to the severe shortage of edible oil, sunflower received a great attention from the high authorities since 1987 (Awad, 2000). The local production of edible oil satisfies $3 \%$ only of the total requirements of the country. The total annual consumption of edible oil is about 2.6 million tons (Anonymous, 2018).

For increasing the total production of edible oil, the cultivated with oil crops such as sunflower should be increased, and the best agricultural practices such as improving of soil fertility by using the best combination of mineral and organic fertilizers which may ultimately increase crop yields should be conducted. Sunflower like other green plants requires at least 16 elements for growth, most of these elements are obtained from the soil. The nutrients extracted from the soil return to the soil or by the easy means of adding fertilizers. Use of fertilizers, especially, the chemical fertilizers has brought in blessings on humanity, which helped contain hunger and death in different corners of the world. Though chemical fertilizers increase crop production, its not only nourish plants and microbes, but also may have harmful effects on the soil and its life, especially when they are very concentrated and water soluble. Acidification as well as neutralization of the soil may be very harmful to microbes, which often depend on a sole enzyme. And enzymes are active only in a very specific $\mathrm{pH}$. Changes in $\mathrm{pH}$ slow down enzyme reaction, and microbes have to enter into rest, encysting, or die from hunger. Accordingly; scientists and researchers are seen arguing in favor of organic fertilizers as the best solution to avoid soil pollution and many other threats to environment and life caused by overuse of chemical fertilizers.

Humic acid (HA) is one of the main organic fertilizers, which is an important component of humic substances it is produced by the chemical and biological decomposition of organic material. It has an important role as a vital component of soil organic matter which improves the growth of many plant species due to enhances of soil fertility and improves soil physical and chemical characteristics, like permeability, aeration, aggregation, water holding capacity, ion transport and availability through $\mathrm{pH}$ buffering, Tan (2003). Masciandaro et al. (2002) indicated that humic substances might enhance the uptake of nutrients and reducing the uptake of some toxic elements. Russo and Berlyn (1990) reported that, humates (granular and liquid 
forms) can reduce plant stress that involved plant diseases as well as enhance plant nutrient uptake. The increment of growth parameters and crop yields due to Humic acid (HA) application may be attributed to that Humic acid (HA) is an important component since it constitutes a stable fraction of carbon, thus regulating the carbon cycle and release of nutrients, including nitrogen, phosphorus, and sulfur, which decreasing the need for inorganic fertilizer for plant growth. Humic substances are usually applied to the soil, and favorably affect the soil structure and soil microbial populations. The purpose of this work aimed to determine the effect of application of different levels of humic acid along with mineral fertilizers on sunflower yield and its component and identify the best combination of humic acid with mineral fertilization which provide higher yield under investigation conditions.

\section{MATERIALS AND METHODS}

To investigate the effect of different levels of humic acid application along with several levels of mineral fertilizers on growth and productivity of sunflower, two field experiments were conducted at Itay EL-Baroud Station, EL-Behyra Governorate, Egypt in two successive summer seasons of 2016 and 2017. The treatments included fife levels of mineral fertilizers in combination with humic acid, i.e. T1 (100\% mineral fertilizers + zero humic acid), T2 (75\% mineral fertilizers +2 litters of humic acid/feddan), T3 (50\% mineral fertilizers +2 litter of humic acid/feddan), T4 (50\% mineral fertilizers +1 litter of humic acid/feddan) and $\mathrm{T} 5$ ( $0 \%$ mineral fertilizers +2 litter of humic acid/feddan), foliar application of humic was done on 25,35 and 45 day after sowing (DAS). Two varieties were used in this study named, Sakha 53 and Giza 102 obtained from Oil Crops Research Department, Field Crops Research Institute (ARC), Giza, Egypt. A split plot design with three replications was used, the main plots were designed to the varieties, while the sub plots were designed to fertilization levels. The sowing dates in 2016 and 2017 seasons were at $16^{\text {th }}$ and $20^{\text {th }}$ of may, respectively. Each sub plot consisted of fife rows with $4 \mathrm{~m}$ long and $60 \mathrm{~cm}$ apart with $20 \mathrm{~cm}$ between hills. Agricultural practices were followed as recommended including the irrigation processes, to keep the crop free from weeds hand hoeing was done twice. The two outside rows were left to avoid border effect and ten guarded plants were randomly taken from third row of each experimental plot for determining growth and yield attributes i.e. plant height $(\mathrm{cm})$, days to $50 \%$ flowering, stem diameter $(\mathrm{cm})$, head diameter $(\mathrm{cm})$, seed yield/plant $(\mathrm{gm})$, seed yield/feddan $(\mathrm{kg}), 1000$-seed weight (gm), number of seeds/plant and oil \%. Before planting sunflower soil was analyzed for some physical and chemical properties according to Cottenie et al. (1982) as shown in Table (1).

The simple benefit cost ratio was calculated using the formula according to Fathima et al. (2013) = Gross returen

Cost of cultivation

All recorded data were analyzed using COSTAT version 6.311 according to Sendecor and Cochran (1976). The least significant differences (LSD) were used to test the significance between varieties mean at $95 \%$ level of probability.

Table (1): Some physical and chemical properties of the experimental soil.

\begin{tabular}{ccc}
\hline Soil analysis & $\mathbf{2 0 1 6}$ & $\mathbf{2 0 1 7}$ \\
\hline & Physical properties & \\
\hline Clay\% & 54.8 & 52.74 \\
Silt \% & 24.2 & 25.95 \\
Sand \% & 21.0 & 22.51 \\
Texture & Clay & Clay \\
\hline & Chemical properties & 0.88 \\
OM \% & 0.56 & 8.00 \\
PH & 7.8 & 1.54 \\
EC, dsm & 1.95 & 47 \\
N (PPm) & 50 & 40 \\
P (PPm) & 47 & 229 \\
K(PPm) & 241 & \\
\hline
\end{tabular}




\section{RESULTS AND DISCUSSION}

\section{Performance of cultivars}

Data in Table (2) refer to highly significant differences between sunflower cultivars for all studied characters during the two seasons. These differences could be due to differences existed in their gentical background, these result are harmony with these obtained by AbdAllah (2004) and Toaima et al. (2004). In general Sakha 53 surpassed and gave higher values than cultivar Giza 102 in all studied traits except Oil \% recorded good values of plant height, head diameter, stem diameter, no. of seed/pl during the two seasons.

\section{Effect of humic acid and mineral fertilization on studied characters}

According to the results indicated in Table (2) significant differences were recorded between treatments (humic acid and mineral fertilizers levels) for all studied characters except flowering date, 1000 seed weight (gm) in 2017 and physiological maturity date during the two seasons 2016 and 2017.

In general the first and second fertilizers treatments surpassed all other fertilizers treatments in all studied traits except oil $\%$, the $4^{\text {th }}$ and $5^{\text {th }}$ treatments gave higher $\%$ than other treatments. With regard to the effect of different doses of humic acid and mineral fertilizers on days to $50 \%$ flowering of two sunflower cultivars, the treatments T4 and T3 recorded the best values in 2016 season, while, T3 and T2 were the best treatments in 2017. For physiological maturity date no significant differences were found among treatments during the two seasons. The highest value of plant height (187.49 and $185 \mathrm{~cm}$ ) observed under T1, however, the lowest values were observed under T5 for 2016 and 2017 seasons, difference in plant height may be due to sufficient mineral fertilizers especially nitrogen fertilizer in the form of urea, these results are in agreement with those obtained by Mishra et al. (2010).

Concerning head diameter it ranged from (18.75 to 21.23 ) and (18.48 to 21.25) during 2016 and 2017 seasons respectively. The maximum head diameter recorded by $\mathrm{T} 1$ and $\mathrm{T} 2$ during the two seasons, Cosage and Bayrakter (2004) indicated head diameter as the most significant yield component and Kaya et al. (2009) indicated yield increases until ahead diameter of $24 \mathrm{~cm}$, contra wise oil contents decreased until head diameter increased. Stem diameter found to be high value when T1 and T2 applied during the two seasons, values of stem diameter was higher in 2017 than 2016 that may caused by temperature.

Regarding to no. of seeds/plant also $\mathrm{T} 1$ and $\mathrm{T} 2$ recorded the highest numbers of seeds/head due high head diameter during the two growing seasons 2016 and 2017.
With respect to 1000 -seed weight data showed that thousand seed weight of the year 2016 higher than 2017 and the greatest value was obtained from (T1 and T2) during the two seasons, increasing thousand seed weight caused by increasing nitrogen fertilization in $\mathrm{T} 1$ and $\mathrm{T} 2$, while reducing in this character among the rest treatments were found it means that humic acid can limit reducing need for mineral fertilizers by enhance nutrients up take. For seed/plant, it's clear that the best values of seed yield/plant were found in 2016 compared to 2017 , the application of $\mathrm{T} 1$ and $\mathrm{T} 2$ resulted in significantly higher seed yield/plant during the two seasons, while, no significant found between $\mathrm{T} 1$ and $\mathrm{T} 2$ in 2017 season. With regard to seed yield/fed, high number of seeds/plant and high value of 1000-seed weight, head diameter and seed yield/plant lead to high value of seed yield/fad, it was higher with $\mathrm{T} 1$ compared to other applications in 2016 but no significant differences were observed between $\mathrm{T} 1$ and $\mathrm{T} 2$ in2017. These results are in conformity with those reported by Hakoomat et al. (2004) and Sadras (2006).

According to the data in Table (2) high oil \% achieved when T5 and T4 were applied and the lowest percent were found with $\mathrm{T} 1$ and $\mathrm{T} 2$ it means that increasing mineral fertilization specially nitrogen fertilizer decreased oil percent Similar responses have been reported in another study by Scheiner et al. (2002), Syed et al. (2003) and Aleman et al. (2002).

\section{Interaction between cultivars $x$ fertilization treatments}

With regard to the interaction between cultivars and fertilization (combination of humic and minerals fertilizers) the results showed that highly significant interaction were found for plant height in 2017, stem diameter and seed weight in 2016 and no. of seeds/plant, seed yield/plant and seed yield/fad during the two seasons, while, no significant were found for the rest characters. At T1 and T2 the cultivar Sakha 53 gave the maximum values for most characters during the two seasons, while Giza 102 exhibited the best results for flowering date and oil \%. In general we can conclude that reducing mineral fertilizers up to $75 \%$ don't lead to reduction in yield if humic acid is added additionally quality of seed yield and oil content may be better.

\section{Economics}

The analyzied data in Table (4) showed the economics of application of different levels of humic acid and mineral fertilizers and it indicated that highest gross return of $\left(6773.5\right.$ and 6596.55 L.E/fed $\left.{ }^{-1}\right)$ in 2016 and $\left(6847.71\right.$ and $\left.6768.94 \mathrm{~L} . \mathrm{E} / \mathrm{fed}^{-1}\right)$ in 2017 by T1 and T2 respectively. Regarding benefit cost ratio best values (1.346 and 1.317) and (1.380 and 1.361) observed in T1 and $\mathrm{T} 2$ during the two seasons, the results also showed that the cultivar Sakha 53 more profitable than the cultivar Giza 102. 
Table (2): Effect of different levels of humic acid and mineral fertilizers on growth and productivity of two sunflower cultivars during 2016 and 2017 seasons

\begin{tabular}{|c|c|c|c|c|c|c|c|c|c|c|}
\hline \multirow{2}{*}{ Treatments } & \multicolumn{2}{|c|}{$\begin{array}{c}\text { days to } \\
50 \% \text { flowering } \\
\end{array}$} & \multicolumn{2}{|c|}{$\begin{array}{l}\text { physiological } \\
\text { maturity date }\end{array}$} & \multicolumn{2}{|c|}{ Plant height (cm) } & \multicolumn{2}{|c|}{$\begin{array}{c}\text { Head diameter } \\
(\mathrm{cm})\end{array}$} & \multicolumn{2}{|c|}{$\begin{array}{c}\text { Stem diameter } \\
(\mathrm{cm})\end{array}$} \\
\hline & 2016 & 2017 & 2016 & 2017 & 2016 & 2017 & 2016 & 2017 & 2016 & 2017 \\
\hline T1 & 54 & 52.33 & 76.5 & 76.6 & 187.49 & 185 & 21.23 & 21.25 & 1.26 & 2.06 \\
\hline $\mathbf{T} 2$ & 55.5 & 52.5 & 76.33 & 76.33 & 181.5 & 180.66 & 21.58 & 20.81 & 1.21 & 2.05 \\
\hline T3 & 55.66 & 53.5 & 76.33 & 76.33 & 178.07 & 177.66 & 19.9 & 19.5 & 1.12 & 1.87 \\
\hline T4 & 55.83 & 52.33 & 76.33 & 76.33 & 173.21 & 172.83 & 19.48 & 19.03 & 1.09 & 1.78 \\
\hline T5 & 55.5 & 53.33 & 75.66 & 75.66 & 169.54 & 171.83 & 18.75 & 18.48 & 1.04 & 1.73 \\
\hline L.S.D 0.05 & 1.73 & 1.12 & ns & ns & 1.80 & 1.07 & 0.91 & 0.63 & 0.05 & 0.03 \\
\hline \multicolumn{11}{|c|}{ Cultivars } \\
\hline Cultivars & 2016 & 2017 & 2016 & 2017 & 2016 & 2017 & 2016 & 2017 & 2016 & 2017 \\
\hline Sakha 53 & 59.26 & 56.73 & 80.86 & 80.93 & 193.53 & 204.95 & 22.23 & 22.20 & 1.3 & 2.08 \\
\hline G102 & 51.40 & 48.86 & 71.6 & 71.6 & 162.40 & 150.26 & 18.54 & 17.42 & 1.00 & 1.70 \\
\hline L.S.D0.05 & 2.73 & 1.03 & 1.14 & 1.03 & 1.13 & 1.52 & 0.91 & 0.57 & 0.063 & 0.09 \\
\hline Interaction & Ns & $\mathrm{ns}$ & $\mathrm{ns}$ & ns & $\mathrm{ns}$ & $* * *$ & $\mathrm{~ns}$ & ns & $* * *$ & $* *$ \\
\hline
\end{tabular}

Table (2): Cont.

\begin{tabular}{|c|c|c|c|c|c|c|c|c|c|c|}
\hline \multirow{2}{*}{ Treatments } & \multicolumn{2}{|c|}{ No. of seeds/plant } & \multicolumn{2}{|c|}{ 1000seed weight (gm) } & \multicolumn{2}{|c|}{$\begin{array}{c}\text { Seed yield/plant } \\
\text { (gm) }\end{array}$} & \multicolumn{2}{|c|}{$\begin{array}{c}\text { Seed } \\
\text { yield/fad (kg) }\end{array}$} & \multicolumn{2}{|c|}{ Oil \% } \\
\hline & 2016 & 2017 & 2016 & 2017 & 2016 & 2017 & 2016 & 2017 & 2016 & 2017 \\
\hline T1 & 1132.33 & 1058.66 & 75.01 & 62.5 & 83.30 & 63.18 & 988.83 & 999.66 & 38.33 & 38.08 \\
\hline $\mathbf{T 2}$ & 1125.5 & 1053.33 & $72 . .90$ & 51.2 & 82.44 & 62.21 & 864.83 & 988.16 & 38.60 & 38.83 \\
\hline T3 & 982.5 & 1017.66 & 60.90 & 57.58 & 71.30 & 58.38 & 846.33 & 942.66 & 39.50 & 39.88 \\
\hline T4 & 975.83 & 991.16 & 65.85 & 54.56 & 63.61 & 54.76 & 771.5 & 899.66 & 40 & 40.25 \\
\hline T5 & 830.16 & 879.66 & 63.8 & 51.8 & 59.95 & 50.73 & 710.33 & 851.83 & 41 & 40.80 \\
\hline L.S.D 0.05 & 9.94 & 7.03 & 0.92 & 12.71 & 0.88 & 1.00 & 24.48 & 12.08 & 0.6 & 0.69 \\
\hline \multicolumn{11}{|c|}{ Cultivars } \\
\hline Cultivars & 2016 & 2017 & 2016 & 2017 & 2016 & 2017 & 2016 & 2017 & 2016 & 2017 \\
\hline Sakha 53 & 1146.06 & 1071.46 & 71.85 & 55.68 & 84.08 & 64.87 & 952.53 & 1019.8 & 38.80 & 38.74 \\
\hline G102 & 872.46 & 924.2 & 66.77 & 55.38 & 60.16 & 50.83 & 720.2 & 853 & 40.24 & 40.40 \\
\hline L.S.D0.05 & 8.83 & 4.97 & 1.82 & 15.55 & 1.83 & 0.91 & 42.91 & 10.96 & 0.99 & 0.65 \\
\hline Interaction & $* * *$ & $* * *$ & $* * *$ & ns & $* * *$ & $* * *$ & $* * *$ & $* * *$ & ns & $\mathrm{ns}$ \\
\hline
\end{tabular}


Table (3): The interaction between levels of humic acid and mineral fertilizers and two sunflower cultivars for some growth and yield, yield attributes during 2016 and 2017 seasons

\begin{tabular}{|c|c|c|c|c|c|c|c|c|c|c|c|c|}
\hline \multirow{3}{*}{ Treatments } & \multirow{2}{*}{\multicolumn{2}{|c|}{$\begin{array}{c}\begin{array}{c}\text { Plant height } \\
(\mathrm{cm})\end{array} \\
2017\end{array}$}} & \multicolumn{4}{|c|}{ Seed yield/plant (gm) } & \multirow{2}{*}{\multicolumn{2}{|c|}{$\begin{array}{c}\begin{array}{c}\text { Stem } \\
\text { diameter } \\
(\mathrm{cm})\end{array} \\
2016\end{array}$}} & \multicolumn{4}{|c|}{ No. of seeds/head } \\
\hline & & & \multicolumn{2}{|c|}{2016} & \multicolumn{2}{|c|}{2017} & & & \multicolumn{2}{|c|}{2016} & \multicolumn{2}{|c|}{2017} \\
\hline & $\begin{array}{c}\text { Sakha } \\
53\end{array}$ & $\begin{array}{c}\text { Giza } \\
102\end{array}$ & $\begin{array}{c}\text { Sakha } \\
\mathbf{5 3}\end{array}$ & $\begin{array}{c}\text { Giza } \\
102\end{array}$ & $\begin{array}{c}\text { Sakha } \\
53\end{array}$ & $\begin{array}{c}\text { Giza } \\
102\end{array}$ & $\begin{array}{c}\text { Sakha } \\
53\end{array}$ & $\begin{array}{c}\text { Giza } \\
102\end{array}$ & $\begin{array}{c}\text { Sakha } \\
53\end{array}$ & $\begin{array}{c}\text { Giza } \\
102\end{array}$ & $\begin{array}{c}\text { Sakha } \\
53\end{array}$ & $\begin{array}{c}\text { Giza } \\
102\end{array}$ \\
\hline T1 & 212.67 & 157.33 & 102.79 & 63.82 & 73.02 & 53.34 & 1.47 & 1.06 & 1282.66 & 982 & 1164.33 & 953 \\
\hline $\mathbf{T 2}$ & 211 & 150.33 & 101.51 & 63.36 & 72.65 & 51.78 & 1.4 & 1.03 & 1285 & 966 & 1163.66 & 943 \\
\hline T3 & 206 & 149.33 & 80.32 & 62.29 & 66.14 & 50.62 & 1.24 & 1.00 & 1119.66 & 845.33 & 1092.66 & 942.66 \\
\hline T4 & 198.33 & 147.33 & 68.96 & 58.27 & 57.75 & 51.78 & 1.22 & 0.97 & 1107 & 844.66 & 1056.33 & $926 \mathrm{e}$ \\
\hline T5 & 196.66 & 147 & 66.82 & 53.08 & 54.82 & 46.65 & 1.16 & 0.933 & $936 \mathrm{e}$ & 724.33 & 903 & 856.33 \\
\hline L.S.D 0.05 & 1.52 & & 1.25 & & 1.42 & & 0.069 & 0.069 & 14.06 & & 9.94 & \\
\hline
\end{tabular}

\section{Table (3): Cont}

1000-seed weight (gm)

Yield/fad (kg)

\begin{tabular}{|c|c|c|c|c|c|c|}
\hline \multirow[t]{2}{*}{ Treatments } & \multicolumn{2}{|c|}{2016} & \multicolumn{2}{|c|}{2016} & \multicolumn{2}{|c|}{2017} \\
\hline & Sakha 53 & Giza 102 & Sakha 53 & Giza 102 & Sakha 53 & Giza 102 \\
\hline T1 & 78.2 & 71.83 & 1220.33 & 757.33 & 1116.66 & 882.66 \\
\hline $\mathbf{T 2}$ & 76.13 & 69.66 & 977.33 & 752.33 & 1112 & 864.33 \\
\hline $\mathbf{T 3}$ & 72.36 & 65.63 & 953.33 & 739.33 & 1035 & 850.33 \\
\hline T4 & 67.6 & 64.1 & 818.33 & 724.33 & 935 & 864.33 \\
\hline T5 & 64.96 & 62.63 & 793.33 & 627.33 & 900.33 & 803.33 \\
\hline
\end{tabular}


Table (4): Economics of effect of different levels of humic acid and mineral fertilizers on yield/feddan during 2016 and 2017

\begin{tabular}{|c|c|c|c|c|c|c|}
\hline \multirow{2}{*}{ Treatments } & \multicolumn{2}{|c|}{ Cost of cultivation (L.E) } & \multicolumn{2}{|c|}{ Gross return (L.E) } & \multicolumn{2}{|c|}{ B.C ratio } \\
\hline & 2016 & 2017 & 2016 & 2017 & 2016 & 2017 \\
\hline $\mathrm{T} 1$ & $5025 \mathrm{a}$ & $5025 \mathrm{a}$ & $6773.50 \mathrm{a}$ & $6847.71 \mathrm{a}$ & $1.346 \mathrm{a}$ & $1.380 \mathrm{a}$ \\
\hline $\mathrm{T} 2$ & $5003 \mathrm{~b}$ & $5003 \mathrm{~b}$ & $6596.55 \mathrm{a}$ & $6768.94 \mathrm{a}$ & $1.317 \mathrm{a}$ & $1.361 \mathrm{~b}$ \\
\hline $\mathrm{T} 3$ & $4750 \mathrm{c}$ & $4750 \mathrm{c}$ & $5797.38 \mathrm{~b}$ & $6457.26 \mathrm{~b}$ & $1.219 \mathrm{~b}$ & $1.358 \mathrm{~b}$ \\
\hline $\mathrm{T} 4$ & $4626 \mathrm{~d}$ & $4626 \mathrm{~d}$ & $5284.77 \mathrm{c}$ & $6162.71 \mathrm{c}$ & $1.150 \mathrm{c}$ & $1.352 \mathrm{~b}$ \\
\hline T5 & 4226 e & $4226 \mathrm{e}$ & $4865.78 \mathrm{~d}$ & $5835.05 \mathrm{~d}$ & $1.142 \mathrm{~d}$ & 1.331 \\
\hline L.S.D 0.05 & 2.25 & 2.25 & 185.73 & 82.77 & 0.039 & 0.017 \\
\hline \multicolumn{7}{|c|}{ Cultivars } \\
\hline Cultivairs & 2016 & 2017 & 2016 & 2017 & 2016 & 2017 \\
\hline Sakha 53 & $4751.4 \mathrm{a}$ & $4751.4 \mathrm{a}$ & $6793.83 \mathrm{a}$ & $6985.63 \mathrm{a}$ & $1.420 \mathrm{a}$ & $1.468 \mathrm{a}$ \\
\hline G102 & $4700.6 \mathrm{~b}$ & $4700.6 \mathrm{~b}$ & $4933.37 \mathrm{~b}$ & $5843.05 \mathrm{~b}$ & $1.049 \mathrm{~b}$ & $1.245 \mathrm{~b}$ \\
\hline L.S.D0.05 & 1.98 & 1.98 & 313.26 & 75.10 & 0.066 & 0.015 \\
\hline
\end{tabular}

L.E $=$ Egyptian pound

\section{CONCLSION}

From the previous results, it could be concluded that treatments $\mathrm{T} 1$ and $\mathrm{T} 2$ showed more promising results as compared to rest treatments, so it could be recommended that applying of humic acid combined with $75 \%$ of mineral fertilizers didn't differ significantly from using mineral fertilizers alone and it can decrease the cost of production and enhance seed yield and oil \% quality.

\section{REFERENCES}

Abd-Alla, M. M. S. and W. A. EL-Sawy (2004). Laboratory and yield evaluation of peanut seed quality. Ann. of Agric. Sci., Moshtohor, 41(2): 537-553.

Aleman, P. R., S. L. Cholaky, O. Giayetto, A. J. Machado and H. O. Fundora (2002). Nitrogen fertilizer application in sunflower in carbonate soil in the central region of Cuba. Centro Agricola, 29: 56-63

Anonymous (2018). Growing and production of sunflower.ARC, Giza, Egypt.

Awad, M. M. (2000). Evaluation of some sunflower hybrids under different levels of nitrogen fertilization. Ph.D. Thesis, Fac. Agric., Tanta. Univ., Egypt.
Cottenie, A. M. Verloo, L. Kiekens, G. Velgh and R. Camerlynck (1982). Chemical Analysis of Plants and Soils. P 44-45. State Univ. Ghent Belgium, 63.

Cosge, B. and N. Bayraktar (2004). Correlations between some yield and yield components in sunflower (Helianthus annuus L.) hybrid, line and varieties. Journal of agricultural science, 10(1): 111-115.

Duane, R. Berglund (2007). Sunflower production. NDSU Extension Service, N. D. Agricultural Experiment Station, North Dakota State University, America.

Fathima, F. A. and G. R. Denesh (2013). Influence of humic acid spray on growth and yield of chili (Capsicum annum L.). International. J. Agric. Sci., 9(2): 542- 546

Ghobadian, B., H. Rahimi, T. T. Hashjin and M. Khatamifra (2008). Production of bioethanol and sunflower methyl Ester and investigation of fuel blend properties. J. Agric . Sci. Technol., 10(3): 225-232.

Hakoomat, A., S. A. Randhawa and Y. Muhammad (2004). Effect of planting dates and nitrogen application on yield potential and oil contents of sunflower. Ind. J. Plant Sci., 3: 224-228

Izquierdo, N., L. Aguirreza'bal, F. Andrade and V. Pereyra (2002). Night temperature affects fatty acid composition in sunflower oil depending on 
the hybrid and the phenological stage. Field Crops Res., 77: 115-126.

Kaya, Y., G. Evci, V. Pekcan, T. Gucer and M. İ. Yilmaz (2009). The determination relationships between oil yield and some yield traits in sunflower. Ankara University Faculty of Agriculture, Journal of Agricultural Sciences, 15(4): 310-318.

Masciandaro, G., B. Ceccanti, V. Ronchi, S. Benedicto and L. Howard (2002). Humic substances to reduce salt effect on plant germination and growth. Commun. Soil. Sci. Plant. Anal., 33: 365378.

Mishra, A., K. Prasad and G. Rai (2010). Effect of biofertilizer inoculations on growth and yield of dwarf field pea (Pisum sativum L.) in conjunction with different doses of chemical fertilizers. J Agron., 9: 163-168.

Russo, R. O and G. P. Berlyn (1990). The use organic biostimulants to help low input sustainable agriculture. J. of Sust. Agric., 1(2): 19-42.

Sadras, V. O. (2006). The N: Pstiochiometry of cereal, grain legume and oilseed crops. Field Crop Res., 95: 13-29.

Scheiner, J. D., F. H. B. Gutierrez and R. S. Lavado (2002). Sunflower nitrogen requirement and ISN fertilizer recovery in Western Pampas, Argentina. Eur. J. Agron., 17: 73-79.

Snedecor, G. W. and W. G .Cochran (1976). Statistical methods. Seventh Edition. Iowa State Univ. Press, Ames, Iowa, USA.

Syed, T. H. M., M. R. Ganai, A. Tahir and A. Shahid (2003). Effects of N x S interaction on the nutrient uptake, yield and quality of sunflower (Helianthus annuus L.) under temperate conditions of Kashmir. Nat. J. Plant Improv., 5: 47-49.

Tan, K. H. (2003). Humic Matter in Soil and the Environment. Principles and Controversies. University of Georgia. Athens, Georgia, U.S.A.

Thomaz, G. L., J. Zagonel, L. O. Colasante and R. R. Nogueira (2012). Yield of sunflower and oil seed content as a function of air temperature, rainfall and solar radiation. Cienc Rural, 42(8): 13801385.

Tooaima, S. E., A. R. A. Attalla and W. A. El-Sawy (2004). Response of some peanut genotypes to intercropping with sesame in relation to yield components. Annals of Agric. Sci. Moshtohor., 42: 903-916. 


\section{تأثثر التسميد العضوي والمعدني على نمو وإنتاجية دوار الشمس}

\section{خميس عبد الجيد دياب مراد ، وائل محمد عادل خليل تعيلب}

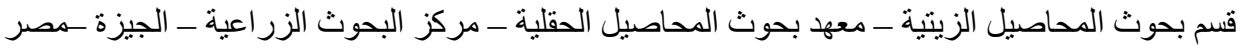

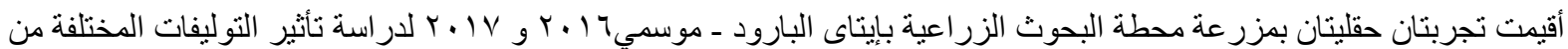

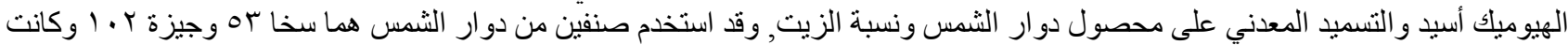

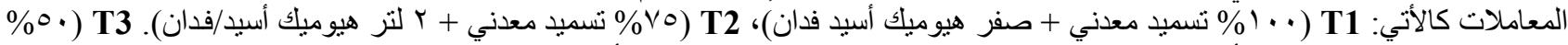

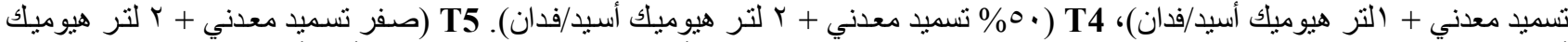

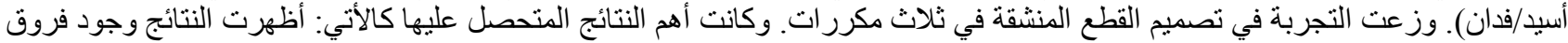

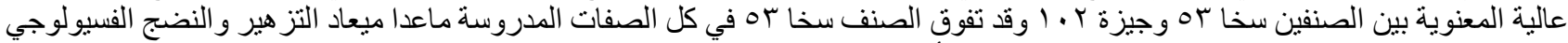

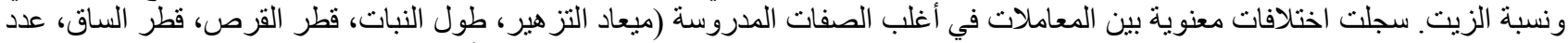

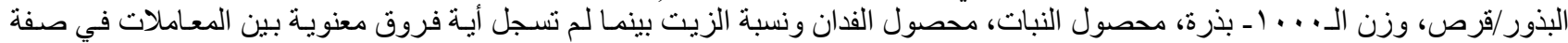

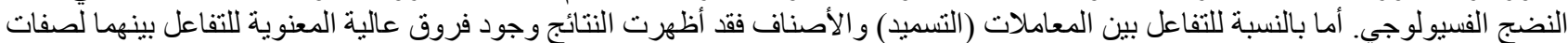

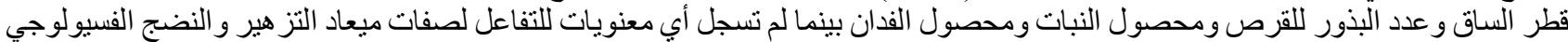

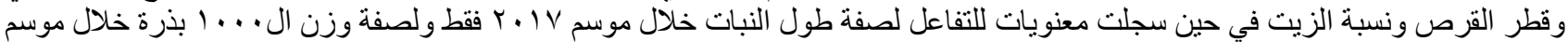

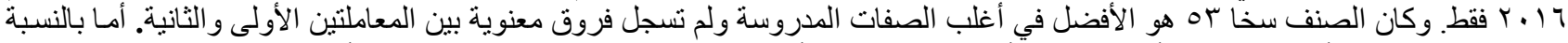

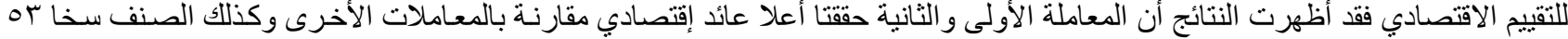

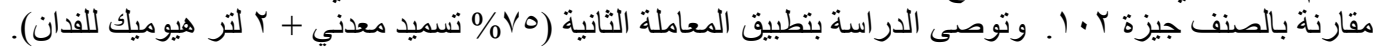

